\title{
PREVALENCE, TYPE AND ETIOLOGY OF DENTAL AND SOFT TISSUE INJURIES IN CHILDREN IN CROATIA
}

\author{
Josip Škaričić ${ }^{1}$, Marko Vuletić ${ }^{2}$ Sandra Hrvatin ${ }^{3}$, Jesenka Jeličić ${ }^{4}$, \\ Ivana Čuković-Bagić ${ }^{5}$ and Hrvoje Jurić ${ }^{5}$
}

${ }^{1}$ Private Practice, Split; ${ }^{2}$ Private Practice, Sisak; ${ }^{3}$ Department of Pediatric Dentistry and Orthodontics, School of Medicine, University of Rijeka, Department of Dental medicine, Rijeka University Hospital Center, Rijeka; ${ }^{4}$ Private Practice, Zagreb; ${ }^{5}$ Department of Pediatric and Preventive Dentistry, School of Dental Medicine, University of Zagreb, Zagreb, Croatia

\begin{abstract}
SUMMARY - The prevalence, type and etiology of dental and soft tissue injuries and relationship between the time of arrival and sustaining soft tissue injury were analyzed in this retrospective study conducted at the Department of Pediatric Dentistry, University Dental Clinic in Zagreb, Croatia, during the 2010-2014 period using documentation on 447 patients (264 male and 183 female) aged 1-16 years with injuries of primary and permanent teeth. The highest prevalence of traumatic dental injury (TDI) was found in the 7-12 age group and maxillary central incisors were most frequently affected (80.9\%) in both primary and permanent dentitions. Enamel-dentin fracture without pulp exposure (31.9\%) was the most common TDI of dental hard tissue in both dentitions, whereas subluxation $(27.3 \%)$ was the most common periodontal tissue injury type. The most frequent location, cause and seasonal variation of trauma were at home, falling and spring. Soft tissue injuries were observed in 203 (45.4\%) patients. Soft tissue injuries were less likely when fewer teeth were traumatized $(p<0.001)$. Comparison of children with and without soft tissue injuries yielded a statistically significant difference in the time to arrival between primary and permanent teeth $(p<0.01)$. Because soft tissue injuries include bleeding and clinical presentation appears more dramatic, the time elapsed between injury and initial treatment was shorter than in non-bleeding injuries, pointing to the need of education focused on parents and school teachers regarding the importance of immediate therapy for both bleeding and non-bleeding TDIs.
\end{abstract}

Key words: Tooth, deciduous; Dentition, permanent; Tooth injuries; Soft tissue injuries

\section{Introduction}

Orofacial injuries cause pain, as well as aesthetic, psychological, behavioral and functional problems among children with traumatized primary and permanent dentition ${ }^{1-4}$. Traumatic dental injuries (TDI) are surpassing dental caries and periodontal disease to become the major threat to young people's dental health ${ }^{1,5,6}$. Although oral area makes only $1 \%$ of human body, oral tissue injuries are the sixth most common

Correspondence to: Marko Vuletić, DMD, Private Practice, Žitna 8, HR-44000 Sisak, Croatia

E-mail:vulesk@gmail.com

Received October 23, 2014, accepted December 1, 2014 body injuries 7 . Studies have shown that 35\%-50\% of children have sustained traumatic injuries of primary and permanent dentition ${ }^{8,9}$.

The reviewed literature shows that males aged 10-12 years experience dental trauma most often, and the majority of trauma (71\%-92\%) occur before the age of $19^{10}$. Maxillary central incisors usually are the teeth that are most affected in both types of dentition. Recent studies have shown a reduction in gender difference due to the characteristics of Western society ${ }^{11}$. Generally, TDI in children and adolescents is associated with damage to the oral soft tissue (lips, tongue and gingiva). Oral soft tissue injuries connected to TDI are present in nearly half of all dental trauma patients ${ }^{12,13}$. 
Glendor ${ }^{11}$ presents four reasons why TDI is a public dental health problem. Because there are no recent studies of the prevalence of TDI in children in Zagreb, Croatia, the aim of this study was to analyze the prevalence, type and etiology of dental and soft tissue injuries. Furthermore, the study demonstrated the connection between TDI and soft tissue injuries and examined the relationship between the time of arrival and presence of soft tissue injury.

\section{Materials and Methods}

This retrospective study was conducted at the Department of Pediatric Dentistry, University Dental Clinic in Zagreb, Croatia, using documentation on 447 patients (264 male and 183 female) aged 1-16 years with injuries to primary and permanent teeth between February 2010 and January 2014. Charts with incomplete medical information were excluded from analysis. Information from trauma charts was organized by age, gender, place and source of trauma, hour and season of trauma, interval between injury and treatment, number of traumatized teeth, injured teeth, type of trauma, and soft tissue injuries. Radiographs were also used to classify hard and periodontal tissue damage. The type of trauma was classified according to Andreasen and Andreasen ${ }^{14}$ classification, as follows:

- injuries to the hard tissue and the pulp: enamel fracture, enamel-dentin fracture without pulp exposure, enamel-dentin fracture with pulp exposure, crown-root fracture, root fracture and alveolar fracture; and

- injuries to the periodontal tissue: concussion, subluxation, displacement, intrusion, extrusion and avulsion.

Soft tissue injuries were divided into upper and lower lip, tongue, gingival, and lip and gingiva injuries. Dental injuries of primary and permanent dentitions were analyzed separately in three age groups (1-6, $7-12$, and 13-16). TDI was classified according to the most serious damage if a specific tooth had more than one type of injury.

Ethical approval for this study was obtained from the Ethics Committee of the School of Dental Medicine, University of Zagreb, Croatia.

Statistical analysis was performed using descriptive statistics and Pearson's $\chi^{2}$-test using Predictive Analytics software (PASW) for Windows version 17.0 (SPSS
Inc., Chicago, IL, USA). The level of significance was set at $5 \%$.

\section{Results}

Of the 447 patients attending the University Dental Clinic in Zagreb, there were $59.1 \%$ of male and $40.9 \%$ of female patients, yielding a 1.5:1 male to female ratio. Patient age ranged from 1 to 16 years (mean $\pm \mathrm{SD}=8.2 \pm 3.8$ years). The highest prevalence of TDI was found in the 7- to 12-year age interval (Fig. 1). Trauma was seen in 217 primary and 542 permanent teeth, in total 759 analyzed teeth. Thus, the number of injured primary teeth was 1.69 per child, and the number of injured permanent teeth was 1.7 per child. The most frequently affected primary teeth were maxillary central incisors $(81.1 \%)$, followed by maxillary lateral incisors (15.6\%). The most frequently affected permanent teeth were maxillary central incisors (80.9\%), followed by maxillary lateral incisors (11.9\%). In both groups, the left side was more affected than the right side, and mandibular teeth were less affected than maxillary teeth.

The most commonly observed TDI of the dental hard tissue and pulp in both primary and permanent dentitions was enamel-dentin fracture without pulp exposure (31.9\%), followed by enamel-dentin fracture with pulp exposure (18.2\%) and enamel fracture (11.1\%). Analyzing periodontal tissue injury in both types of dentition, subluxation was the most common type (27.3\%). Far behind subluxation were avulsion (8.2\%) and intrusion (8.0\%). The types of dental and periodontal injuries were found to be highly signifi-

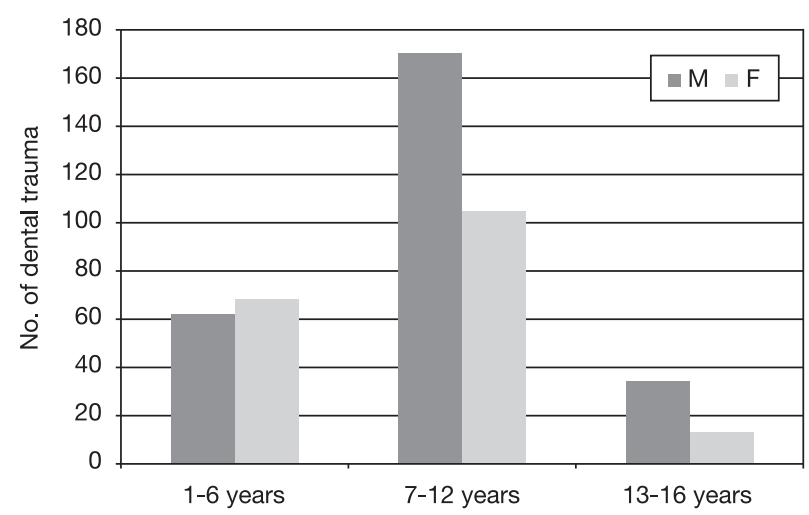

Fig. 1. Distribution of traumatic dental injuries according to age and gender. 
Table 1. Distribution of trauma type according to age groups

\begin{tabular}{|c|c|c|c|c|c|c|c|c|}
\hline & \multicolumn{6}{|c|}{ Injuries to hard dental tissue and pulp } & \multirow[b]{2}{*}{ Total } \\
\hline & & $\begin{array}{l}\text { Enamel } \\
\text { fracture }\end{array}$ & $\begin{array}{l}\text { ED fracture } \\
\text { without pulp } \\
\text { exposure }\end{array}$ & $\begin{array}{l}\text { ED fracture } \\
\text { with pulp } \\
\text { exposure }\end{array}$ & $\begin{array}{c}\text { Root } \\
\text { fracture }\end{array}$ & $\begin{array}{l}\text { Crown-root } \\
\text { fracture }\end{array}$ & None & \\
\hline & & $\mathrm{n}(\%)$ & $\mathrm{n}(\%)$ & $\mathrm{n}(\%)$ & $\mathrm{n}(\%)$ & $\mathrm{n}(\%)$ & $\mathrm{n}(\%)$ & $\mathrm{n}(\%)$ \\
\hline \multirow{3}{*}{ Age (yrs) } & $1-6$ & $9(10.7)$ & $24(9.9)$ & $21(15.2)$ & $3(27.2)$ & $5(35.7)$ & $155(57.4)$ & $217(28.6)$ \\
\hline & $7-12$ & $68(81)$ & $183(75.6)$ & $92(66.7)$ & $7(63.7)$ & $5(35.7)$ & $93(34.4)$ & $448(59)$ \\
\hline & $13-16$ & $7(8.3)$ & $35(14.5)$ & $25(18.1)$ & $1(9.1)$ & $4(28.6)$ & $22(8.2)$ & $94(12.4)$ \\
\hline \multirow{4}{*}{\multicolumn{2}{|c|}{ Total }} & $84(100)$ & $242(100)$ & $138(100)$ & $11(100)$ & $14(100)$ & $270(100)$ & $759(100)$ \\
\hline & & \multicolumn{6}{|c|}{ Injuries to periodontal tissue } & \\
\hline & & Subluxation & Intrusion & Extrusion & Avulsion & Displacement & None & Total \\
\hline & & $\mathrm{n}(\%)$ & $\mathrm{n}(\%)$ & $\mathrm{n}(\%)$ & $\mathrm{n}(\%)$ & $\mathrm{n}(\%)$ & n \%) & $\mathrm{n}(\%)$ \\
\hline \multirow{3}{*}{ Age (yrs) } & $1-6$ & $90(43.5)$ & $39(63.9)$ & $14(35.9)$ & $28(45.2)$ & $4(36.3)$ & $42(11.1)$ & $217(28.6)$ \\
\hline & $7-12$ & $96(46.4)$ & $18(29.5)$ & $22(56.4)$ & $27(43.5)$ & $5(45.5)$ & $280(73.9)$ & $448(59)$ \\
\hline & $13-16$ & $21(10.1)$ & $4(6.6)$ & $3(7.7)$ & $7(11.3)$ & $2(18.2)$ & $57(15)$ & $94(12.4)$ \\
\hline \multicolumn{2}{|l|}{ Total } & $207(100)$ & $61(100)$ & $39(100)$ & $62(100)$ & $11(100)$ & $379(100)$ & $759(100)$ \\
\hline
\end{tabular}

$\mathrm{ED}=$ enamel-dentin

cantly associated with age $\left(\chi^{2}=187.267, \chi^{2}=127.659\right.$, $\mathrm{df}=10 ; \mathrm{p}<0.001)$ (Table 1).

Among different age groups, falls were the most frequent cause of TDI (52.1\%: 35.6\% at home, 24\% at school and $15.6 \%$ in sports), followed by collisions with objects (17.9\%: $33.7 \%$ in sports, $31.2 \%$ at school and $22.5 \%$ at home) and bicycle/rolling accidents (9.6\%: $51.2 \%$ free time, $27.9 \%$ in sports and $18.6 \%$ at home). The rarest cause was violence (only $2 \%$ ). Differences in the distribution of the location and cause of accidents were highly significant $(\mathrm{p}<0.001)$.

Traumatic dental injuries occurred primarily in spring $(n=123 ; 27.5 \%)$, followed by autumn $(n=121$; $27.1 \%)$, summer $(n=104 ; 23.3 \%)$ and winter $(n=99$; 22.1\%). Differences were observed in the distribution of seasonal accidents between the genders. Males were injured more often in autumn, and females were injured more often in spring $(\mathrm{p}<0.05)$. The results also showed differences in the distribution between different age groups and seasons. Children aged 1-6 experienced TDIs in spring and summer (39 cases), whereas children aged 7-16 experienced TDIs in autumn (88 cases) $(\mathrm{p}<0.05)$.

The majority of children with primary and permanent teeth had TDIs between 4 p.m. and 7 p.m.

Of the 447 patients that received treatment for TDIs, 203 (45.4\%) also had soft tissue injuries. Distri- bution of soft tissue injuries by gender (113 males and 80 females) was not statistically significant $(\mathrm{p}=0.351)$. Of the overall number of patients with soft tissue injuries, 71 were preschoolers, and 132 were aged 7-16 years. The highest percentage of preschoolers had soft tissue injures at the age of 2 (25.4\%), and the highest percentage of school-age children had soft tissue injuries at the age of 9 (19.7\%). Soft tissue injuries were less likely when a smaller number of teeth were traumatized $(\mathrm{p}<0.001)$. Multiple dental injuries ( 2 teeth $66.7 \%, 3$ teeth $17.4 \%, 4$ teeth $12.1 \%$ and more than 4 teeth $3.8 \%$ ) were found in $65 \%$ of the patients with soft tissue injuries, while $35 \%$ of patients had only one traumatized tooth. Of the total number of children, $25.7 \%$ had an injury to the upper lip, 9.8\% had an injury to the upper lip and gingiva, $9.6 \%$ had injured gingiva, and only one patient $(0.2 \%)$ had a tongue injury. Table 2 shows distribution of periodontal and dental hard tissue injuries to soft tissue injuries $(\mathrm{p}<0.001)$.

The time elapsed between TDIs and initial treatment indicated that $33.6 \%$ of the children sought treatment within 1-7 days, and $28.9 \%$ sought treatment in 2-24 hours. In the group of children with an injured primary tooth, most of them (32\%) received treatment within 2-24 hours, and $34.5 \%$ of the children with permanent teeth received treatment in 1-7 
Table 2. Distribution of soft tissue injuries to hard and periodontal tissue injuries in both dentitions

\begin{tabular}{|l|c|c|c|c|c|c|}
\hline \multirow{2}{*}{ Type of trauma } & \multicolumn{7}{|c|}{ Soft tissue injuries } & & \\
\cline { 2 - 7 } & Upper lip & Tongue & Gingiva & $\begin{array}{c}\text { Upper lip } \\
\text { and gingiva }\end{array}$ & None & Total \\
\hline Injuries to hard dental tissue and pulp & $\mathrm{n}(\%)$ & $\mathrm{n}(\%)$ & $\mathrm{n}(\%)$ & $\mathrm{n}(\%)$ & $\mathrm{n}(\%)$ & $\mathrm{n}(\%)$ \\
\hline Enamel fracture & $27(12.6)$ & $0(0.0)$ & $7(8.2)$ & $7(6.8)$ & $43(12.1)$ & $84(11.1)$ \\
ED fracture without pulp exposure & $73(33.9)$ & $0(0.0)$ & $8(9.4)$ & $14(13.6)$ & $147(41.5)$ & $242(31.9)$ \\
ED fracture with pulp exposure & $53(24.7)$ & $2(100)$ & $1(1.2)$ & $12(11.7)$ & $70(19.8)$ & $138(18.2)$ \\
Crown-root fracture & $0(0.0)$ & $0(0.0)$ & $1(1.2)$ & $4(3.9)$ & $6(1.7)$ & $11(1.4)$ \\
Root fracture & $5(2.3)$ & $0(0.0)$ & $2(2.4)$ & $2(1.9)$ & $5(1.4)$ & $14(1.8)$ \\
None & $57(26.5)$ & $0(0.0)$ & $66(77.6)$ & $64(62.1)$ & $83(23.5)$ & $270(35.6)$ \\
Total & $215(100)$ & $2(100)$ & $85(100)$ & $103(100)$ & $354(100)$ & $759(100)$ \\
\hline Injuries to periodontal tissue & $\mathrm{n}(\%)$ & $\mathrm{n}(\%)$ & $\mathrm{n}(\%)$ & $\mathrm{n}(\%)$ & $\mathrm{n}(\%)$ & $\mathrm{n}(\%)$ \\
\hline Subluxation & $63(29.3)$ & $0(0.0)$ & $32(37.6)$ & $43(41.7)$ & $69(19.5)$ & $207(27.3)$ \\
Intrusion & $18(8.4)$ & $0(0.0)$ & $5(5.9)$ & $13(12.7)$ & $25(7.1)$ & $61(8)$ \\
Extrusion & $12(5.5)$ & $0(0.0)$ & $5(5.9)$ & $11(10.7)$ & $11(3.1)$ & $39(5.1)$ \\
Avulsion & $4(1.9)$ & $0(0.0)$ & $34(40)$ & $18(17.5)$ & $6(1.7)$ & $62(8.3)$ \\
Displacement & $1(0.5)$ & $0(0.0)$ & $2(2.4)$ & $2(1.9)$ & $6(1.7)$ & $11(1.4)$ \\
None & $117(54.4)$ & $2(100)$ & $7(8.2)$ & $16(15.5)$ & $237(66.9)$ & $379(49.9)$ \\
Total & $215(100)$ & $2(100)$ & $85(100)$ & $103(100)$ & $354(100)$ & $759(100)$ \\
\hline
\end{tabular}

$\mathrm{ED}=$ enamel-dentin

Table 3. Distribution of time elapsed between injury and treatment according to the presence of soft tissue injuries

\begin{tabular}{|c|c|c|c|c|}
\hline \multirow{3}{*}{$\begin{array}{l}\text { Time } \\
\text { elapsed }\end{array}$} & \multicolumn{2}{|c|}{ Primary teeth } & \multicolumn{2}{|c|}{ Permanent teeth } \\
\hline & $\begin{array}{c}\text { Without } \\
\text { STI }\end{array}$ & $\begin{array}{c}\text { With } \\
\text { STI }\end{array}$ & $\begin{array}{c}\text { Without } \\
\text { STI }\end{array}$ & $\begin{array}{l}\text { With } \\
\text { STI }\end{array}$ \\
\hline & $\mathrm{n}(\%)$ & $\mathrm{n}(\%)$ & $\mathrm{n}(\%)$ & $\mathrm{n}(\%)$ \\
\hline $\begin{array}{l}\text { Up } \\
2 \mathrm{~h}\end{array}$ & $1(1.8)$ & 13 (18.3) & $17(9.1)$ & 19 (14.4) \\
\hline $\begin{array}{l}2-24 \\
\text { hours }\end{array}$ & $14(24.6)$ & $27(38)$ & 39 (20.9) & 49 (37.1) \\
\hline 1-7 days & $20(35)$ & $20(28.2)$ & $67(35.8)$ & $43(32.6)$ \\
\hline 8-30 days & $11(19.3)$ & $3(4.2)$ & $17(9.1)$ & $16(12.1)$ \\
\hline$>31$ days & $11(19.3)$ & $8(11.3)$ & $47(25.1)$ & $5(3.8)$ \\
\hline Total & $57(100)$ & $71(100)$ & $187(100)$ & $132(100)$ \\
\hline
\end{tabular}

$\mathrm{STI}=$ soft tissue injuries

days. Data on the time elapsed changed when soft tissue injuries were included. Comparison of children with and without soft tissue injuries yielded a statistically significant difference in the time to arrival between primary and permanent teeth $(\mathrm{p}<0.01)$ (Table 3$)$.

\section{Discussion}

This research was conducted because there are no data on previous studies of dental trauma to primary and permanent teeth and soft tissue injuries in Croatia. The only published study similar to the present one was conducted on permanent teeth in the town of Rijeka ${ }^{15}$ at the end of the last decade. Our research was conducted in the Croatian capital, at the Zagreb University Dental Clinic, which, in combination with its surroundings, represents approximately one-quarter of the Croatian population.

Although Glendor ${ }^{11}$ states that there is a trend toward reduced gender differences in the distribution of trauma, as confirmed by other studies ${ }^{16,17}$, our study belongs to the group of studies ${ }^{18-20}$ demonstrating that gender differences persist in favor of males (1.5:1). However, in this study, preschool girls showed higher rates of TDI than boys, which is in agreement with Carvalho et al. ${ }^{21}$. The reason for this finding may be that both boys and girls aged 1-6 are exposed to similar risk factors, and there is no difference between the games and sports they play. In contrast, school-aged 
boys are more prone to risky behavior, a lack of discipline, fighting and sports than school-aged girls.

The findings of our study indicated that injuries occurred most often in children aged 7-12, supporting the findings of other authors $8,18,22$. The peak of injuries to primary teeth occurs at the age of 2 and at the age of 9 for permanent teeth. Our findings disagree with the studies by Osuji ${ }^{23}$ and Eyuboglu et al..$^{20}$, but are consistent with the study by Andreasen et al..$^{24}$.

A lack of motor coordination ${ }^{25,26}$ on walking and running is the main reason for TDI in preschool children, whereas in early school-age children, TDIs are most likely due to increased independence at school, playgrounds and sports ${ }^{4,27,28}$.

In agreement with previous studies ${ }^{18-20,29,30}$, this study showed that TDI commonly involved maxillary incisors. This finding may be explained by the fact that these teeth may have inadequate lip coverage and frequently protrude ${ }^{30}$. Furthermore, this study showed a statistically significant difference between the right and left side in favor of the latter. In the reviewed literature, this finding is in agreement only with Caldas and Burgos ${ }^{31}$.

The most common type of trauma in primary teeth was subluxation. Periodontal tissue injuries in primary dentition occurred 2.8 times more often than hard dental tissue injuries, a result similar to other studies $^{3,16,20,28,32}$. This finding can be explained by the periodontal ligament elasticity and alveolar bone resilience ${ }^{26,30}$. In permanent teeth, enamel-dentin fractures without pulp exposure were the most frequent type of injury, which is similar to other studies ${ }^{12,15,18-20,33}$, but contrary to a group of studies that found enamel fracture to be the most frequent type of hard dental tissue injury ${ }^{34-37}$.

In this study, there was a statistically significant relationship between age, gender, location, and cause of injury $(p<0.05)$. Consistent with the results of other studies, the most frequent cause of trauma was fall in both genders and in both primary and permanent teeth $^{17,20,30,38}$. Regarding the location of TDIs, this study found that most injuries occurred at home in children aged 1-6 and at school in children aged 7-12, which is similar to previous studies ${ }^{18,25,39}$. The group of children aged 13-16 sustained TDIs during their free time, in contrast to similar studies ${ }^{18}$. This finding may be explained by the fact that in our study, all accidents in streets and public playfields were recorded as 'free time' injuries, and children of that age spend the majority of their time as free time. Moreover, our city has a deficit of public playfields, and the existing ones have inadequate safety standards.

A few groups of authors ${ }^{38,40-42}$ have reported that the frequency of TDI increases in warm months in comparison with cold months. Our finding that traumas to deciduous teeth occurred in spring and summer months is in agreement with these reports. However, our findings showed the highest frequency of TDI to permanent teeth in autumn, which may be related to the beginning of academic year.

Our results also confirmed the findings of other studies $^{43,44}$ that the majority of affected patients were treated more than 24 hours after accidents. However, the results on the time elapsed between sustaining the injury and receiving dental treatment for primary teeth were higher than in other studies due to incorrect routines by general practitioners in Zagreb. After a trau$\mathrm{ma}$, the patient first goes to his general practitioner, who, rather than treating the TDI, refers the patient to the University Dental Clinic. This results in an unnecessary waste of time and increases the likelihood of post-traumatic complications. Because of this situation, $42.9 \%$ of the patients sought treatment within 24 hours, in comparison to the figure of $62.8 \%$ reported by Choi et al. ${ }^{29}$.

The literature reports a wide range of incidence of oral soft tissue injuries, from $14 \%{ }^{19,45}$ to nearly half of all dental traumas ${ }^{12,13}$. Our finding was $45.4 \%$. The literature shows that the prevalence of soft tissue injuries in association with injuries to the primary teeth was $45.2 \%{ }^{29}$, which is fewer than in our study (55.5\%). The same information was not found for permanent teeth, whereas the finding in the present study was $41.4 \%$.

Patients with combined TDI and oral soft tissue injuries to primary and permanent teeth sought treatment sooner than patients without oral soft tissue injury. This finding is in agreement with previous reports ${ }^{16,18,29}$. The more urgent dental treatment is the result of bleeding tendencies and edema caused by soft tissue damage. Furthermore, the disturbing clinical appearance of the child tends to make parents more anxious and motivates earlier dental treatment.

The prevalence of soft tissue injuries in studies should be considered with caution because this information may not be noted for children seeking help after two weeks (in this study, 84 patients). Fehrenbach 
et $a l .{ }^{46}$ state that mucosa and skin injuries can heal in approximately two weeks.

In conclusion, this study showed that males sustained TDI 1.5 times more often than females. The maxillary central incisors were the most affected teeth in the primary and permanent dentitions. The most common TDI of hard dental and pulp tissue was enamel-dentin fracture without pulp exposure, and the most common type of periodontal tissue injury was subluxation followed by avulsion and intrusion. Regarding the location of dental trauma, this study showed that the main cause was fall. These results are similar to the results of other studies. However, the place of sustaining trauma was related to the age of the child. Thus, TDI tended to occur at home in children younger than 6, at school in those aged 7-12, and in free time in those aged 13-16 years.

Nearly half of all patients had soft tissue injuries together with dental injuries, and these injuries were more likely when a larger number of teeth were traumatized. Because soft tissue injuries include bleeding and clinical presentation appears more dramatic, the time elapsed between the injury and initial treatment was shorter than in non-bleeding injuries. This finding points to the need of education focused on parents and school teachers regarding the importance of immediate therapy for both bleeding and non-bleeding TDIs. Every unnecessary time delay increases the expense and complications of treatment.

\section{References}

1. Andreasen JO, Andreasen FM. Dental traumatology: quo vadis. Endod Dent Traumatol. 1990;6:78-80.

2. Marcenes W, Alessi ON, Traebert J. Causes and prevalence of traumatic injuries to the permanent incisors of school children aged 12 years in Jaragua do Sul, Brazil. Int Dent J. 2000 Apr;50(2):87-92. doi: 10.1002/j.1875-595X.2000.tb00804.x

3. Sennhenn-Kirchner S, Jacobs HG. Traumatic injuries to the primary dentition and effects on the permanent successors - a clinical follow-up study. Dent Traumatol. 2006 Oct;22(5):23741. doi: 10.1111/j.1600-9657.2006.00383.x

4. Altun C, Cehreli ZC, Güven G, Acikel C. Traumatic intrusion of primary teeth and its effects on the permanent successors: a clinical follow-up study. Oral Surg Oral Med Oral Pathol Oral Radiol Endod. 2009 Apr;107(4):493-8. doi: http://dx.doi. org/10.1016/j.tripleo.2008.10.016

5. Marcenes W, al Beiruti N, Tayfour D, Issa S. Epidemiology of traumatic injuries to the permanent incisors of 9-12-year-old schoolchildren in Damascus, Syria. Endod Dent Traumatol. 1999 Jun;15(3):117-23.

6. Petersson GH, Bratthall D. The caries decline: a review of reviews. Eur J Oral Sci. 1996 Aug;104(4 (Pt 2)):436-43. doi: 10.1111/j.1600-0722.1996.tb00110.x

7. Petersson EE, Andersson L, Sörensen S. Traumatic oral vs non-oral injuries. Swed Dent J. 1997;21(1-2):55-68.

8. Borssén E, Holm AK. Traumatic dental injuries in a cohort of 16-year-olds in northern Sweden. Endod Dent Traumatol. 1997 Dec;13(6):276-80.

9. Andreasen JO, Ravn JJ. Epidemiology of traumatic dental injuries to primary and permanent teeth in a Danish population sample. Int J Oral Surg. 1972;1(5):235-9.

10. Glendor U, Halling A, Andersson L, Eilert-Petersson E. Incidence of traumatic tooth injuries in children and adolescents in the county of Västmanland, Sweden. Swed Dent J. 1996; 20(1-2):15-28.

11. Glendor U. Epidemiology of traumatic dental injuries - a 12 year review of the literature. Dent Traumatol. 2008 Dec;24 (6):603-11. doi: 10.1111/j.1600-9657.2008.00696.x

12. Zerman N, Cavalleri G. Traumatic injuries to permanent incisors. Endod Dent Traumatol. 1993 Apr;9(2):61-4.

13. Sae-Lim V, Hon TH, Wing YK. Traumatic dental injuries at the accident and emergency department of Singapore General Hospital. Endod Dent Traumatol. 1995 Feb;11(1):32-6.

14. Andreasen JO, Andreasen FM. Classification, etiology and epidemiology. In: Textbook and Color Atlas of Traumatic Injuries to the Teeth, $3^{\text {rd }}$ ed. Copenhagen: Blackwell Munksgaard; 1994. p. 151-80.

15. Ivancic Jokic N, Bakarcic D, Fugosic V, Majstorovic M, Skrinjaric I. Dental trauma in children and young adults visiting a university dental clinic. Dent Traumatol. 2009 Feb;25(1):84-7. doi: 10.1111/j.1600-9657.2008.00711.x

16. de Amorim Lde F, da Costa LR, Estrela C. Retrospective study of traumatic dental injuries in primary teeth in a Brazilian specialized pediatric practice. Dent Traumatol. 2011 Oct;27(5): 368-73. doi: 10.1111/j.1600-9657.2011.01011.x

17. Traebert J, Peres MA, Blank V, Boell Rda S, Pietruza JA. Prevalence of traumatic dental injury and associated factors among. 12-year-old school children in Florianópolis, Brazil. Dent Traumatol. 2003 Feb;19(1):15-8. doi: 10.1034/j.1600-9657. 2003.00138.x

18. Díaz JA, Bustos L, Brandt AC, Fernandez BE. Dental injuries among children and adolescents aged 1-15 years attending public hospital in Temuco, Chile. Dent Traumatol. 2010 Jun;26(3):254-61. doi: 10.1111/j.1600-9657.2010.00878.x

19. Kirzioğlu Z, Karayilmaz H, Ertürk MS, Koseler Sentut T. Epidemiology of traumatised primary teeth in the west-Mediterranean region of Turkey. Int Dent J. 2005 Oct;55(5):329-33. doi: 10.1111/j.1875-595X.2005.tb00332.x

20. Eyuboglu O, Yilmaz Y, Zehir C, Sahin H. A 6-year investigation into types of dental trauma treated in a paediatric dentistry clinic in Eastern Anatolia region, Turkey. Dent Trau- 
matol. 2009 Feb;25(1):110-4. doi: 10.1111/j.1600-9657. 2008.00668.x

21. Carvalho JC, Vinker F, Declerck D. Malocclusion, dental injuries and dental anomalies in the primary dentition of Belgian children. Int J Paediatr Dent. 1998 Jun;8(2):137-41. doi: 10.1046/j.1365-263X.1998.00070.x

22. Sandalli N, Cildir S, Guler N. Clinical investigation of traumatic injuries in Yeditepe University, Turkey during the last 3 years. Dent Traumatol. 2005 Aug;21(4):188-94. doi: 10.1111/ j.1600-9657.2005.00309.x

23. Osuji OO. Traumatised primary teeth in Nigerian children attending University Hospital: the consequences of delays in seeking treatment. Int Dent J. 1996 Jun;46(3):165-70.

24. Andreasen JO, Andreasen FM, Bakland LK, Flores MT. Epidemiology of traumatic dental injuries. In: Traumatic Dental Injuries - A Manual, $2^{\text {nd }}$ ed. Ames, IA: Blackwell Munksgaard; 1999. p. 8-9.

25. Onetto JE, Flores MT, Garbarino ML. Dental trauma in children and adolescents in Valparaiso, Chile. Endod Dent Traumatol. 1994 Oct;10(5):223-7.

26. Skaare AB, Jacobsen I. Primary tooth injuries in Norwegian children (1-8 years). Dent Traumatol. 2005 Dec;21(6):315-9. doi: 10.1111/j.1600-9657.2005.00362.x

27. Odoi R, Croucher R, Wong F, Mercences W. The relationship between problem behaviour and traumatic dental injury amongst children aged 7-15 years old. Community Dent Oral Epidemiol. 2002 Oct;30(5):392-6. doi: 10.1034/j.1600-0528. 2002.00004.x

28. Nicolau B, Marcenes W, Sheiham A. The relationship between traumatic dental injuries and adolescents' development along the life course. Community Dent Oral Epidemiol. 2003 Aug; 31(4):306-13. doi: 10.1034/j.1600-0528.2003.t01-1-00019.x

29. Choi SC, Park JH, Pae A, Kim JR. Retrospective study on traumatic dental injuries in preschool children at Kyung Hee Dental Hospital, Seoul, South Korea. Dent Traumatol. 2010 Feb; 26(1):70-5. doi: 10.1111/j.1600-9657.2009.00840.x

30. Saroğlu I, Sönmez H. The prevalence of traumatic injuries treated in the pedodontic clinic of Ankara University, Turkey, during 18 months. Dent Traumatol. 2002 Dec;18(6):299-303. doi: 10.1034/j.1600-9657.2002.00093.x

31. Caldas AF Jr, Burgos ME. A retrospective study of traumatic dental injuries in a Brazilian dental trauma clinic. Dent Traumatol. 2001 Dec;17(6):250-3. doi: 10.1034/j.1600-9657. 2001.170602.x

32. Avşar A, Topaloglu B. Traumatic tooth injuries to primary teeth of children aged 0-3 years (Turkey). Dent Traumatol. 2009 Jun;25(3):323-7. doi: 10.1111/j.1600-9657.2008.00695.x

33. Hecova H, Tzigkounakis V, Merglova V, Netolicky J. A retrospective study of 889 injured permanent teeth. Dent Trauma- tol. 2010 Dec;26(6):466-75. doi: 10.1111/j.1600-9657.2010. 00924.x

34. Taiwo OO, Jalo HP. Dental injuries in 12-year old Nigerian students. Dent Traumatol. 2011 Jun;27(3):230-4. doi: 10.1111/j.1600-9657.2011.00997.x

35. Navabazam A, Farahani SS. Prevalence of traumatic injuries to maxillary permanent teeth in 9- to 14-year-old school children in Yazd, Iran. Dent Traumatol. 2010 Apr;26(2):154-7. doi: 10.1111/j.1600-9657.2009.00861.x

36. Malikaew P, Watt RG, Sheiham A. Prevalence and factors associated with traumatic dental injuries (TDI) to anterior teeth of 11-13 year old Thai children. Community Dent Health. 2006 Dec;23(4):222-7.

37. Naidoo S, Sheiham A, Tsakos G. Traumatic dental injuries of permanent incisors in 11- to 13-year-old South African schoolchildren. Dent Traumatol. 2009 Apr;25(2):224-8. doi: 10.1111/j.1600-9657.2008.00749.x

38. Kargul B, Cağlar E, Tanboga I. Dental trauma in Turkish children, Istanbul. Dent Traumatol. 2003 Apr;19(2):72-5. doi: 10.1034/j.1600-9657.2003.00091.x

39. Blinkhorn FA. The etiology of dento-alveolar injuries and factors influencing attendance for emergency care of adolescents in the north west of England. Endod Dent Traumatol. 2000 Aug;16(4):162-5.

40. Perez R, Berkowitz R, Mcilveen L, Forrester D. Dental trauma in children: a survey. Endod Dent Traumatol. 1991 Oct;7(5): 212-3.

41. Garcia-Godoy F, Garcia-Godoy F, Garcia-Godoy FM. Primary teeth traumatic injuries at a private pediatric dental center. Endod Dent Traumatol. 1987 Jun;3(3):126-9.

42. Zeng Y, Sheller B, Milgrom P. Epidemiology of dental emergency visits to an urban children's hospital. Pediatr Dent. 1994 Nov-Dec;16(6):419-23.

43. Lam R, Abbott P, Lloyd C, Lloyd C, Kruger E, Tennant M. Dental trauma in an Australian rural centre. Dent Traumatol. 2008 Dec;24(6):663-70. doi: 10.1111/j.1600-9657.2008. 00689.x

44. Glendor U, Halling A, Bodin L, Andersson L, Nygren A, Karlsson G, et al. Direct and indirect time spent on care of dental trauma: a 2-year prospective study of children and adolescents. Endod Dent Traumatol. 2000 Feb;16(1):16-23.

45. Al-Jundi SH. Dental emergencies presenting to a dental teaching hospital due to complications from traumatic dental injuries. Dent Traumatol. 2002 Aug;18(4):181-5. doi: 10.1034/j. 1600-9657.2002.02081.x

46. Fehrenbach MJ, Lemborn UE, Phelan JA. Inflammation and repair. In: Ibsen OAC, editor. Oral Pathology for the Dental Hygienist. Philadelphia: W.B. Saunders Co; 2000. p. 43-102. 


\section{Sažetak \\ UČESTALOST, VRSTA I ETIOLOGIJA DENTALNIH I MEKOTKIVNIH OZLJEDA KOD DJECE U HRVATSKOJ}

\section{J. Škaričic, M. Vuletic, S. Hrvatin, J. Jeličic, I. Čuković-Bagič i H. Jurić}

Svrha ovoga istraživanja je bila istražiti učestalost, vrstu i etiologiju dentalnih ozljeda te ozljeda mekih tkiva. Također se ispitala korelacija vremena proteklog između ozljede i potražene pomoći kada su bile prisutne i ozljede mekih tkiva. Retrospektivno istraživanje je provedeno na Zavodu za dječju stomatologiju Stomatološkog fakulteta Sveučilišta u Zagrebu u razdoblju od 2010. do 2014. godine koristeći dokumentaciju 447 pacijenata u dobi od 1-16 godina (264 dječaka i 183 djevojčice) s ozljedama mliječnih i trajnih zubi. Najveća učestalost traumatskih dentalnih ozljeda je pronađena u dobnoj skupini od 7 do 12 godina, a gornji središnji sjekutići $(80,9 \%)$ su bili najčešće zahvaćeni zubi u obje denticije. Fraktura cakline i dentina bez izlaganja pulpe (31,9\%) bila je najčešća vrsta ozljede kod tvrdog zubnog tkiva u obje denticije, dok je subluksacija $(27,3 \%)$ bila najčešća vrsta ozljede parodontnog tkiva. Najčešća lokacija, uzrok i godišnje doba traume su bile kod kuće, pad i proljeće. Ozljede mekih tkiva su pronađene kod 203 (45,4\%) pacijenata i bile su češće kod pacijenata koji su imali više traumom zahvaćenih zubi $(\mathrm{p}<0,001)$. Uspoređujući pacijente s ozljedama mekih tkiva i one bez njih statistički značajna razlika pronađena je u vremenu proteklom do potražene stručne pomoći između mliječnih i trajnih zuba $(\mathrm{p}<0,01)$. Zbog toga što ozljede mekih tkiva često uključuju krvarenje cijela klinička slika izgleda mnogo dramatičnije, vrijeme proteklo između ozljede i početnog liječenja bilo je kraće od onoga za ozljede koje nisu uključivale ozljedu mekih tkiva. To pokazuje potrebu za ciljanim obrazovanjem roditelja i učitelja o važnosti neposredne terapije dentalnih ozljeda kao i ozljeda mekih tkiva.

Ključne riječi: Zub, mliječni; Zub, trajni; Zub, ozljede; Meko tkivo, ozljede 